\title{
Learning Anatomy Through Dissection: Perceptions of a Diverse Medical Student Cohort
}

\author{
Aprendizaje de la Anatomía a Través de Disección: Percepción \\ de una Amplia Cohorte de Estudiantes de Medicina
}

Van Wyk, J.* \& Rennie, C.O.**

VAN WYK, J. \& RENNIE C. O. Learning Anatomy through dissection: Perceptions of a diverse medical student cohort. Int. J. Morphol., 33(1):89-95, 2015.

SUMMARY: The debate on how best to teach anatomy and the central role of cadaveric dissections in medical training remains topical even today. Despite the use of a variety of teaching methodologies e.g. prosected specimens, plastinated specimens, cadaveric dissection and computer-assisted learning, the amount of time dedicated to a full body human dissection programme, its clinical relevance and whether it promotes deeper learning has become a bone of contention in problem- based learning context. The implementation of student centred, PBL curricula means that students' learning is autonomous, and studies suggest the link between students' approaches to learning with their perceptions of their learning environment. Therefore, this study explored the perceptions of an educationally diverse medical student cohort in a 5 year problem-based learning programme who learned anatomy through the dissection method, elaborating on the value of this subject to their medical studies. Quantitative and qualitative data was collected and thematically analysed. One hundred students of the MBChB2 cohort (44\%) completed the questionnaire. The majority of the respondents (70\%) reported a positive experience during anatomical dissection in terms of visual and clinical application whilst gaining anatomy understanding and skill. Students with prior educational qualifications (mature) and first time school leavers voiced similar complaints. Student responses differed qualitatively on how they benefitted from the dissection. This study confirms that dissection remains an effective method for basic anatomy teaching even in PBL contexts. It concludes with strategies to enhance the learning experiences of educationally diverse students.

KEY WORDS: Teaching and learning in anatomy; Dissection; Problem based learning; Undergraduate medical program; Student perceptions.

\section{INTRODUCTION}

Students' understanding of gross anatomy, i.e. a branch of anatomy that deals with the structure of organs and tissues visible to the naked eye is foundational to learning medicine. There is much debate about how best to teach anatomy in student-centred, problem-based learning (PBL) contexts. Literature suggests the existence of two perspectives i.e. the traditionalists who favour teaching through dissection of human cadavers (Aziz et al., 2002) and reformers who advocate for the use of a variety of modalities, including prosected specimens, plastinated specimens, computer-assisted software and radiological imaging with cadaveric dissection included as just another strategy to support students' learning in anatomy (McLachlan \& Patten, 2006).
The implementation of student-centred, PBL curricula has impacted on anatomy teaching in that it has resulted in a reduction of lectures with the limited use of dissection as a teaching strategy. This trend has increased not only the debate around the role of the cadaver in anatomy teaching (Pabst, 2009) but also the need to explore the efficiency of anatomical teaching time in PBL curricula. Although traditionalists strongly stress the essential role of the cadaver in students' acquisition of anatomical knowledge, some believe that cadaveric dissection or prosected specimens may not be the most appropriate method in teaching anatomy to the medical student, since the medical practitioner would confront anatomy through forms of li-

\footnotetext{
"Department of Clinical Medicine, Nelson R. Mandela School of Medicine, College of Health Sciences, University of KwaZulu-Natal, KwaZulu-Natal, South Africa.

${ }^{* *}$ School of Laboratory Medicine and Medical Sciences, Department of Clinical Anatomy, College of Health Sciences, University of KwaZulu-Natal, KwaZulu-Natal, South Africa.
} 
ving anatomy and medical imaging (McLachlan et al., 2004). Those who support the use and increase of students learning modalities emphasise the need to ensure the alignment of students' understanding of concepts, their structural relations and its relevance to clinical practice. They stress the acquisition of essential anatomical skills including the power of observation, identification and interpretational abilities, which are essential for effective and safe clinical practice (Boon et al., 2002). Additional issues such as the decreasing pool of skilled anatomy lecturers and technicians, maintenance of cadaveric facilities, fewer cadaveric donations have complicated the debate around teaching in the discipline (Sugand et al., 2013) as well as in the African context (Kramer et al., 2008). According to Bekele et al. (2011), several medical schools in the United Kingdom, for example, have phased out dissection altogether. But, active dissection programmes still remain in the United States, Germany and Africa (Bekele et al., 2011). According to studies the reduction in anatomical teaching has consequences, and, this is being experienced in regard to patient care (Bekele et al.; Sugand et al.).

Although many studies elaborate on how anatomy should be taught, very few focus on student perceptions of anatomical teaching (Lempp, 2005; Moxham \& Plaisant, 2007; Azer \& Eizenberg, 2007; Pabst, 2009; Notebaert, 2009). According to Bergman et al. (2013), students have strong opinions about their anatomical knowledge. These authors suggests that students' opinions may have a far reaching effect on medical curriculum development and future studies that evaluate their perceptions of the factors affecting their learning in anatomy is critical. It is however noted that most studies on anatomical teaching had been conducted in developed countries with very few studies elaborating on the students' experiences especially in the resource constraint African context.

Student conceptions and learning. Studies have demonstrated a strong link between students' approaches to learning, conceptions of learning, perceptions of the learning environment and their ultimate achievement of the learning outcomes (Marton \& Säljö, 1997). According to Azer et al., 2007 student perceptions provide a vision to medical educators to understand the needs of the students, sources of their worries and best approaches for teaching anatomy. Although a number of studies reflect on the physical and emotional stress of anatomy, very few reflect on demographic variables such as sex, academic background and citizenship (Azer et al.).

Educators can gain a better understanding of the conceptions that students use for learning in anatomy to inform the choices made and their decisions around effective teaching in the discipline. In this study we explored the quality of learning of second year medical students in an anatomy dissection programme by drawing on the six category framework of Marton et al. (1993) which had been adapted by McLean (2001) (Table I).

Context and setting. In January 2000, the Nelson R. Mandela School of Medicine (NRMSM) of the University of KwaZulu-Natal (UKZN), introduced a problem-based learning (PBL) curriculum to inculcate more studentcentered and self-directed learning (SDL) approaches at the undergraduate level. Curriculum 2001 (C2001), as it became known, brought about many changes in teaching and learning, the most significant being the replacement of discipline-based teaching with more holistic, integrated, interdisciplinary learning and the use of authentic, real-life patient problems to stimulate learning (Van Wyk, 2009). A desire to make learning more meaningful, relevant and active led to the increased use of the small group learning process. These changes have also impacted on students' education and training within anatomy. However, the effects of these changes on students' learning have not yet been assessed.

Student diversity. Stemming from South Africa's historical past and apartheid policies, the NRMSM became established as a school which uses racial quotas to redress previous historical disadvantage (South African History Online, 2014). The school thus admits both mature and first time school leavers to the first year of the MBChB program. In this context, a mature student would have gathered one or more years of undergraduate or postgraduate experience in a Health Science related field before registering for the MBChB (Singaram et al., 2008 ), while a first time school leavers (FTSL) gains entry to the program directly after their completion of the SA national senior certificate examination (SCE). Since 2010 students entered the programme having schooled on the newly implemented Outcomes-based Education framework. The poor implementation of this system led to great uncertainty around the quality of the Senior Certificate scores at the time. A decision was taken to enrol a larger number of mature learners, whose prior learning experiences included anatomy, would have benefitted and supported their throughput on the programme.

Therefore, taking into account student diversity in education and the current debates about the best way to teach relevant basic science (in particular anatomy) to medical students, a study on student perceptions of their learning and interaction with anatomy was warranted. This study explored a) whether students found the anatomy dissection course beneficial and $b$ ) whether learner diversity i.e. mature and/or FTSL experienced qualitative different experiences on the programme. 
Table I. Overview of Conceptions of learning by Marton et al. (1993).

$\begin{array}{ll}\begin{array}{l}\text { Conception A: } \\ \text { Increasing one's } \\ \text { knowledge }\end{array} & \begin{array}{l}\text { All other conceptions develop from this one. This conception has a strong quantitative nature with no } \\ \text { notion of using what has been learnt. }\end{array} \\ \begin{array}{l}\text { Conception B: } \\ \begin{array}{l}\text { Memorising and } \\ \text { reproducing }\end{array}\end{array} & \begin{array}{l}\text { Learning is seen in quantitative terms aiming to reproduce exactly what is learnt; normally for purposes } \\ \text { of a test or performance as ses sment. }\end{array} \\ \begin{array}{l}\text { Conception C: } \\ \text { Applying }\end{array} & \text { In this conception one retrieves what had been learnt to apply it in response to a need. } \\ \begin{array}{l}\text { Conception: } \\ \begin{array}{l}\text { Understanding } \\ \text { Conception E: }\end{array}\end{array} & \text { This is the first level where meaning is attached implying some significance of what had been learnt. } \\ \begin{array}{l}\text { different way } \\ \text { Conception F: }\end{array} & \text { Here the leaner has changed his/her way about thinking about something or coming to a new perspective } \\ \text { Changing as a person } & \text { on something. }\end{array}$

\section{MATERIAL AND METHOD}

This qualitative study, collected quantitative and qualitative data through a self-administered questionnaire. The MBChB2 cohort $(n=227)$ was purposefully sampled and invited to participate due to their training and exposure to Anatomy. This cohort consisted of students who had entered the program either as first time school leavers (FTSL) or mature learners. Mature learners in this context are those who studied one or more years at a tertiary institution. The second year cohort was introduced and exposed and introduced to concepts in anatomy in their foundational year (year one) and had completed a semester of hands-on anatomical dissection during their second year.

Data Collection and Analysis. The questionnaire was administered during a small group tutorial session where a facilitator informed students of their rights to anonymity and participation. This was after they had completed a semester in dissecting the thorax, abdomen and pelvis. The questionnaire consisted of 5 sections which apart from biographical details also explored their experiences in PBL, small and large group teaching and the dissection program. The questionnaire comprised mainly open-ended statements that explored students' perceptions of the anatomy dissection program and its value in their learning and understanding. The data was captured in an Excel spreadsheet and independently analyzed by each researcher. The themes were verified and agreed upon and related to McLean conceptions of learning at subsequent meetings. In addition, we compared the extent to which FTSL and mature learners reported differences in learning of Anatomy. Ethical approval for the study was obtained via the Human and Social Sciences Ethics Committee of the University of KwaZulu Natal.

\section{RESULTS}

One hundred (44.05\%) completed questionnaires were returned by the cohort. Demographically the cohort $(n=100)$ consisted of 30 males and 70 females (average of 20.1 \pm 1.8 years). The cohort consisted of 62 students who entered the program directly after completion of the senior certificate examination. The remaining 38 students consisted of 35 students who had completed between $>1$ but $<$ than 4 years of tertiary education and one student who had completed 8 years of a Masters in Medical Science qualification. One student reported 10 months experience on an Alternative health and Natural medicine course which included prior Anatomy exposure while one student did not explain the duration and nature of his/her prior experience. Students with prior experience in Anatomy also included 3 students who repeated the second year of the 5 year PBL program. Table II summarizes the responses of student to the question of how the dissection program assisted them in gaining a deeper understanding of the medical content.

Table II. Thematic analysis of student responses towards learning via the dissection.

\begin{tabular}{lcccc}
\hline & Positive & Negative & No comment & Total \\
\cline { 2 - 5 } First Time School Leavers $(\mathrm{n}=62)$ & $42(67.7 \%)$ & $10(16.1 \%)$ & $10(16.1 \%)$ & 62 \\
Mature $(\mathrm{n}=38)$ & $28(60.5 \%)$ & $9(23.6 \%)$ & $1(2.6 \%)$ & 38 \\
Total & 70 & 19 & 11 & 100 \\
\hline
\end{tabular}


In general, an overwhelming majority $(70 \%)$ of the cohort reported positive experiences in learning anatomy through the dissection program. Others (19\%) did not feel that the program added value to their learning. The explanations that students offered to support their perceptions were analyzed to explore how mature $(\mathrm{M})$ and first time school leavers (FTSL) valued their learning. The comments are summarized in Table III. The findings suggest that both the mature and the FTSL, who indicated positive experiences, found the learning through dissection useful. It allowed them to relate the visual and practical material to the clinical content of the PBL themes thereby ensuring greater relevance to the learning of the subject. They also reported expanding their knowledge and gaining an improved understanding while engaged in the supportive network provided by their team of peers.
Whilst students' comments highlighted in Table IV, illustrate their positive perceptions in learning anatomy through dissection, $19 \%$ of the students also indicated that they required more direction in terms of what they were expected to learn during the sessions (Table IV). Students required guidance in dissecting techniques and asked for additional advice from anatomy demonstrators at practical sessions. Students requested that appropriate time be allocated for the dissection sessions and that assessment and curriculum structures be reviewed. Some first time school leavers were not comfortable with learning from the cadaveric and the prosected specimens while mature students seemed comfortable and competent in the subject matter. Some students in this cohort applied to be credited for having completed the required first year Anatomy credits in prior qualifications. They therefore did not attend the anatomical dissection except to refresh their knowledge.

Table III. Comparison of FTSL and Mature learners' perceptions.

\begin{tabular}{|c|c|c|}
\hline Themes & First Time School Leavers & Mature \\
\hline $\begin{array}{l}\text { Knowledge } \\
\text { (Conception A) }\end{array}$ & --- & $\begin{array}{l}\text { "It puts into practice what I know and being } \\
\text { physically able to the see the Anatomical parts } \\
\text { beneficial" (M 10). }\end{array}$ \\
\hline $\begin{array}{l}\text { Visual and Practical } \\
\text { Application } \\
\text { (Conception BCDE) }\end{array}$ & $\begin{array}{l}\text { "It is important to see the various layers of the body } \\
\text { while dissecting. The specimens are not always } \\
\text { sufficient as not all components (nerves, muscles, } \\
\text { veins etc) are present" (FTSL 30). } \\
\text { "In 1st year we did mostly theory and no dissection. } \\
\text { At sec year level we get to see the little details that } \\
\text { make medicine interesting" (FTSL74). }\end{array}$ & $\begin{array}{l}\text { "Dissection allows us to look at the real thing as } \\
\text { opposed to a textbook which is often not realistic } \\
\text { at all" (M 37). } \\
\text { "Anatomy despite what people think is a } \\
\text { practical subject. How will we be good doctors it } \\
\text { we don't know what real structures look like? } \\
\text { DH is a necessity" (M 44). }\end{array}$ \\
\hline $\begin{array}{l}\text { Clinical Relevance } \\
\text { (Conception CD) }\end{array}$ & $\begin{array}{l}\text { "It helps me to relate medical conditions that I learn } \\
\text { during lectures and on textbooks and see how" } \\
\text { (FTSL 20). }\end{array}$ & $\begin{array}{l}\text { "Since I have alr eady done anatomy, it benefits } \\
\text { me to understand the medical content" (M 25). }\end{array}$ \\
\hline $\begin{array}{l}\text { Understanding } \\
\text { (Conception ACD) }\end{array}$ & $\begin{array}{l}\text { "Physically seeing leads to a better understanding } \\
\text { and more retained" (FTSL 78). }\end{array}$ & $\begin{array}{l}\text { "Allows visualisation of body parts i.e. enhances } \\
\text { learning and understanding" (M 61). }\end{array}$ \\
\hline $\begin{array}{l}\text { Teamwork (Conception } \\
\text { EF) }\end{array}$ & --- & $\begin{array}{l}\text { "Each one of us has his/her own station to work } \\
\text { in the labs and felt free to discuss with each } \\
\text { other" (M 93). }\end{array}$ \\
\hline
\end{tabular}

Table IV. Negative perceptions and experiences of FTSL and mature students.

\begin{tabular}{lll}
\hline Themes & \multicolumn{1}{c}{ First Time School Leavers } & \multicolumn{1}{c}{ Mature } \\
\hline $\begin{array}{l}\text { Guidance and } \\
\text { Demonstration }\end{array}$ & $\begin{array}{l}\text { "Less help is available in the DH to assist us in better } \\
\text { understanding of anatomy" (FTSL 43). }\end{array}$ & $\begin{array}{l}\text { "We are not directed adequately. There should be a } \\
\text { practical demonstration. At the moment we know } \\
\text { the theory but cut blindly" (M 50). }\end{array}$ \\
Time & $\begin{array}{l}\text { "Dissection is time consuming and there is } \\
\text { insufficient time left for theoretical learning. } \\
\text { Prosected specimens are useful though." (FTSL 75) }\end{array}$ & $\begin{array}{l}\text { "We spend time dissecting but it is difficult to see as } \\
\text { we are inexperienced in proper dissection" (M 71). }\end{array}$ \\
Assessments & $\begin{array}{l}\text { "Approach to teaching is not successful. Marks are } \\
\text { the proof" (FTSL 96). }\end{array}$ & \\
Organization & "We need more structure" (FTSL 33). & \\
Learning & Cadavers are different from live people and the & \\
Resources/tools & specimens are old and rugged" (FTSL 64) & "I did not attend" (M 17). \\
Attendance & & -
\end{tabular}


Table V. Suggestions to improve students' engagement and learning.

Themes
Prior reading
(Conceptions
ABCDE)

Clear dissection
guidelines

Increase in lectures

Increase number of demonstrators/ supervisors

More guidance during dissection Use of prosected specimens

\begin{abstract}
"We are able to physically see what we are studying but I feel that if a dissection is given to us before hand and then told to dissect then it would be even better. Sometimes students misinterpret the guidelines given in the book and most important structures are damaged or cut off" (FTSL 5).
\end{abstract}

"To an extent it is useful to see the actual body parts, it aid in memory and understanding. However lectures are not sufficient number and info, and we aren't taught from the cadaver" (FTSL 30).

"Less help is available in the DH to assist us in better understanding of anatomy" (FTSL 43).

"Dissection is time consuming and there is insufficient time left for theoretical learning. Prosected specimens are useful though" (FTSL 75).

\section{Mature}

"I found it easier to understand anatomy when I read, then go to DH to dissect and identify structures on the cadaver $r$ ather than seeing it in the book only. Dissection makes human anatomy more realistic" (M 27)

We are able to physically see what we are learning from the tex tbook, although good guidelines like a lecture before dissection, so that dissection would be more orientated" (M 39).

\section{"Cadavers should be explained to us, especially while dissecting" (M 14).}

Despite having indicated an overall rewarding dissection experience, students provided some suggestions to further improve their understanding in anatomy. These themes indicated in Table $\mathrm{V}$ relate to their preparation prior to attending an anatomical dissection session. They suggested the need for additional and clearer dissection guidelines prior to each session, the scheduling of anatomy lectures in aid of the dissection sessions and allocation of more demonstrators to improve the staff: student ratio in the dissection hall. Students also required the use of additional resources e.g. prosected specimens to aid their understanding especially where keen inexperienced dissectors might have removed valuable structures before the rest of the group assigned to the cadaver, could observe the required structure.

\section{DISCUSSION}

Both mature $(67.7 \%)$ and FTSL $(60.5 \%)$ on the $\mathrm{MBChB} 2$ cohort reported overall positive experiences. They valued the programme because it helped them gain a deeper understanding of the medical content. The most valued aspect cited by both groups related to the visual and practical application of the cadaveric dissection and their appreciation of the three-dimensional form of the structures and how they are related. This learning activated their senses of sight and touch and it increased their understanding of anatomy. This appreciation of visual and practical stimuli is essential when students, as future practicing doctors are called upon to examine patients (Lempp).

"I found it easier to understand anatomy when I read, then go to DH to dissect and identify structures on the cadaver rather than seeing it in the book only. Dissection makes human anatomy more realistic" (M 27) (Conception ABCDE).

Considering that these students are relatively inexperienced self-directed learners it is rewarding to note that the reported conceptions spanned the scale of Marton et al. categories from being reproductive where they aimed just to increase their knowledge to transformative where students' insights improved due to their engagement with their peers.

None of the students in this study indicated that they had memorised names and structures as evident in a study by Pandey \& Zimitat (2007). These authors suggested that students often learn anatomy by adopting more than two approaches, such as using a combination of visual stimulation, understanding and/or memorisation. In this study, students claimed that they learned for understanding; primarily through visual and tactile stimuli through the use of the human cadaver. This study showed that the process of anatomical dissection aided their orientation and three dimensional mental picture of the human body, which presumably helped them to learn and retain the information. These findings are similar to those of Yeager (1996) who found that students benefit from forming mental models rather than relying on memorisation. 
"Because when you are dissecting you are able to see exactly what you have been reading about by seeing in a real person which makes it easy to learn it and retain it." (Visual, knowledge, retention) (FTSL 55) (Conception CD)

"It is more educative to see the real thing and sometimes we get to see how structures perform their functions instead of just imagining it from textbooks." (Visual, understanding) (FTSL 73) (Conception F).

Learning in anatomy by dissection provided students with a clearer understanding of how to connect concepts. This seemingly helped them to gain a deeper understanding which is regarded as necessary for deep and satisfying learning as opposed to strategic and surface learning strategies (Entwistle \& Tait, 1995).

Furthermore, this echoes the sentiments of Korf $e t$ al. (2008) in which they showed that the production and reproduction of the skill of anatomical dissection conserved existing practised knowledge that is transferred to the students' mind.

Students further indicated that learning through the dissection provided them with a foundation which would be useful as future doctors. This aspect is especially important in a medical curriculum and further supports the philosophy of problem-based learning where a deeper understanding of the basic sciences is essential in relating scientific concepts to practical clinical examples which is important in developing their cognitive skills.

On comparison, mature learners benefitted more in terms of enjoying learning within their teams. This may be due to their more active leadership, confidence when sharing during discussions and dissection sessions. The confidence may also be due to having a better understanding of the requirements for success and knowledge of the essential areas to be covered. These students were thus able to start and finish dissection tasks more efficiently than their FTSL counterparts. This is reflected in the quotation, "Each one of us has his/her own station to work in the labs and felt free to discuss with each other" (M 93).

First time school leavers on the other hand indicated that they became demotivated by poor assessment results and perceived a lack of guidance and curriculum structure. The first three years of the medical curriculum now focuses on developing and laying a firmer foundation for basic sciences. This re-arrangement has increased the dissection time in the first three years. However, it does become apparent that this arrangement would be difficult since the anatomy teaching will not coincide or be aligned with the organ-systems as covered in the PBL themes and modules. Making use of additional learning tools in the anatomical dissection laboratory e.g. plastinated specimens, the latest anatomy computer programs and radiological imaging such as magnetic resonance imaging would enhance students' learning. This is in keeping with studies that have suggested the use of models and Computerassisted learning (CAL) to supplement dissection programs to improve the quality of training (Egwu et al., 2008). These resources may also alleviate problems that may be encountered with cadaver numbers, especially since basic anatomy needs to be covered over a three year period.

Lastly, both groups in the cohort offered some suggestions to enhance their learning (Table V). First time school leavers felt that their learning experience would improve through prior exposure to dissection techniques, adequate allocation of demonstrators for guidance in terms of knowledge and skills, adequate allocation of lectures and practical demonstrations to guide them prior to dissections, and use of other resources such as prosected specimens. Mature students felt that prior reading and proper dissection guidelines would enhance their learning. While both groups impressed upon the value of the demonstrator, surprisingly, the mature students suggested that demonstrators should teach them from the cadaver in order to expand and develop their existing base of knowledge and prior experience.

In conclusion, this article reported on the value of the dissection programme for second year medical students. Positive perceptions and experiences were reported by the majority in the cohort. Mature and FTSL students offered suggestions which would help to solidify their anatomical knowledge. Finally, this study confirmed that PBL students continue to learn from the cadaver and that its value in teaching and learning in Anatomy remains.

VAN WYK, J. \& RENNIE C. O. Aprendizaje de la anatomía a través de disección: Percepciones de una amplia cohorte de estudiantes de medicina. Int. J. Morphol., 33(1):89-95, 2015.

RESUMEN: El debate sobre la mejor manera de enseñar la anatomía y la relevancia de las disecciones de cadáveres en la formación médica sigue siendo un tema de actualidad. A pesar del uso de una variedad de metodologías de enseñanza, por ejemplo especímenes plastinados, la disección de cadáveres y el aprendizaje asistido por computador, el tiempo dedicado a un programa de disección de cuerpo completo, su relevancia clínica y el promover un aprendizaje más profundo se ha convertido en un tema de discordia en el contexto del aprendizaje de los estudiantes y sus percepciones del ambiente de aprendizaje. Este estudio investigó las percepciones desde un punto de vista educativo en un grupo de estudiantes de medicina en un programa de aprendizaje basado un estudio observacional, en un programa de 5 años basado en problemas a través del método de disección, evaluando el valor de este tema para sus estudios de medicina. Los datos cuantitativos y cualitativos fueron recolectados y analizados temáticamente. Un centenar de estudiantes de la cohorte MBChB2 
(44\%) completaron el cuestionario. La mayoría de los encuestados (70\%) reportó una experiencia positiva durante la disección anatómica en términos de aplicación visual y clínica, mientras van adquiriendo comprensión de la anatomía y habilidad. Los estudiantes con títulos de estudios previos (maduros) y los recién egresados de la escuela secundaria expresaron quejas similares. Las respuestas de los estudiantes difieren cualitativamente en la forma en que se beneficiaron de la disección. Este estudio confirma que la disección sigue siendo un método eficaz para la enseñanza de anatomía básica incluso en contextos de ABP. El estudio concluye con estrategias para mejorar las experiencias de aprendizaje de los estudiantes basado en diversos problemas.

PALABRAS CLAVE: Enseñanza y aprendizaje en anatomía; Disección; Aprendizaje en base a problemas; Programa médico de pregrado; Percepción de los alumnos.

\section{REFERENCES}

Azer, S. A. \& Eizenberg, N. Do we need dissection in an integrated problembased learning medical course? Perceptions of first- and second-year students. Surg. Radiol. Anat., 29(2):173-80, 2007.

Aziz, M. A.; McKenzie, J. C.; Wilson, J. S.; Cowie, R. J.; Ayeni, S. A. \& Dunn, B. K. The human cadaver in the age of biomedical informatics. Anat. Rec., 269(1):20-32, 2002.

Bekele, A.; Reissig, D.; Löffler, S. \& Hinz, A. Experiences with dissection courses in human anatomy: a comparison between Germany and Ethiopia. Ann. Anat., 193(2):163-7, 2011.

Bergman, E. M.; de Bruin, A. B.; Herrler, A.; Verheijen, I. W.; Scherpbier, A .J. \& van der Vleuten, C. P. Students' perceptions of anatomy across the undergraduate problem-based learning medical curriculum: a phenomenographical study. B. M. C. Med. Educ., 13:152, 2013.

Boon, J. M.; Meiring, J. H. \& Richards, P. A. Clinical anatomy as the basis for clinical examination: development and evaluation of an Introduction to Clinical Examination in a problem-oriented medical curriculum. Clin. Anat., 15(1):45-50, 2002.

Egwu, O. A.; Ugwu, A. C.; Eteudo, A. N.; Ewunonu, E. O. \& Njoku, C. O. Perceptions of medical students undergoing cadaveric training: a sociocognitive perspective. Int. J. Med. Update, 3(2):8-12, 2008.

Entwistle, N. \& Tait, H. Approaches to studying and perceptions of the learning environment across disciplines. New Dir. Teach. Learn., 1995(64):93-103, 1995.

Korf, H. W.; Wicht, H.; Snipes, R. L.; Timmermanns, J. P.; Paulsen, F.; Rune, G. \& Baumgaut-Vogt, E. The dissection course - necessary and indispensable for teaching anatomy to medical students. Ann. Anat., 190(1):16-22, 2008.

Kramer, B.; Pather, N. \& Inhunwo, A. O. Anatomy: spotlight on Africa. Anat. Sci. Educ., 1(3):111-8, 2008.

Lempp, H. K. Perceptions of dissection by students in one medical school: beyond learning about anatomy. A qualitative study. Med. Educ., 39(3):318-25, 2005 .

Marton, F.; Dall'Alba, G. \& Beaty, E. Conceptions of learning. Int. J. Educ. Res., 19(3):277-300, 1993.
Marton, F. \& Säljö, R. Approaches to learning. In: Marton, F.; Hounsell, D. \& Entwistle, N. (Eds.). The experience of learning. Edinburgh, Scottish Academic Press, 1997.

McLachlan, J. C.; Bligh, J.; Bradley, P. \& Searle, J. Teaching anatomy without cadavers. Med. Educ., 38(4):418-24, 2004.

McLachlan, J. C. \& Patten, D. Anatomy teaching: ghosts of the past, present and future. Med. Educ., 40(3):243-53, 2006.

McLean, M. Can we relate conceptions of learning to student academic achievement? Teach. High. Educ., 6:400-13, 2001.

Moxham, B. J. \& Plaisant, O. Perception of medical students towards the clinical relevance of anatomy. Clin. Anat., 20(5):560-4, 2007.

Notebaert, A. J. Student perceptions about learning anatomy. PhD diss. Iowa, University of Iowa, 2009. Available in: http://ir.uiowa.edu/etd/ 312

Pabst, R. Anatomy curriculum for medical students: what can be learned for future curricula from evaluations and questionnaires completed by students, anatomists and clinicians in different countries? Ann. Anat., 191(6):541-6, 2009.

Pandey, P. \& Zimitat, C. Medical students' learning of anatomy: memorisation, understanding and visualisation. Med. Educ., 41(1):714, 2007.

Singaram, V. S.; Dolmans, D. H.; Lachman, N. \& van der Vleuten, C. P. Perceptions of problem-based learning (PBL) group effectiveness in a socially-culturally diverse medical student population. Educ. Health (Abingdon), 21(2):116, 2008.

South Africa's History Online (SAHO). Youth and the National Liberation Struggle. 2014. Available in: http://www.sahistory.org.za/topic/bantueducation-policy.

Sugand, K.; Abrahams, P. \& Khurana, A. The anatomy of anatomy: a review for its modernization. Anat. Sci. Educ., 3(2):83-93, 2010.

Van Wyk, J. The progress examination as an assessment tool in a problem based learning curriculum: A case study of the Nelson R. Mandela School Of Medicine. PhD Thesis. Durban, University of KwaZuluNatal, 2009.

Yeager, V. L. Learning gross anatomy: dissection and prosection. Clin. Anat., 9(1):57-9, 1996.

Correspondence to:

Dr. Jacqueline van Wyk

Clinical and Professional Education

School of Clinical Medicine

Umbilo Campus

University of KwaZulu-Natal

KwaZulu-Natal

SOUTH AFRICA

Email: vanwykj2@ukzn.ac.za

Received: 04-07-2014 Accepted: 24-10-2014 